\title{
Analysis of the relation between safety perception and the degree of civil participation as a tool of sustainable development
}

\author{
J. Betáková ${ }^{1}$, M. Lorko ${ }^{1}$, J. Dvorský ${ }^{2} \&$ M. Škoda ${ }^{1}$ \\ ${ }^{I}$ Dubnica Institute of Technology, Slovakia \\ ${ }^{2}$ University of Žilina, Slovakia
}

\begin{abstract}
Building an advanced society based on sustainable values is inherently linked with terms such as freedom, justice, progress, independence, democracy and, not least, safety. Provided the citizens face the consequences of public decisionmaking, their involvement into all the stages of the developmental process of the objective area is obvious and legitimate that makes the potential for its higher transparency and effectiveness. The study deals with a deep analysis of the relation between safety perception and the level of civil participation.

Keywords: environmental management, spatial management, sustainable development.
\end{abstract}

\section{Introduction}

Cities are the driving force of the European economy. Generally, they are considered to be a creativity and innovation accelerator within E.U. terms. Approximately 70 per cent of the E.U. population lives in metropolitan areas generating about 70 per cent of the E.U. gross domestic product. That's also the reason why the urban development integrated policy plays a significant role; being the prerequisite for the implementation of particular development policies in the context of European strategy of sustainable development.

In this context, the Leipzig Charter on Sustainable European Cities (2007) is based on the presumption that municipalities must mobilize the public and private sector, unify their interests and set controlling measures for the implementation of integrated regional development. Within these processes, engagement of all economic actors, concerned subjects and the general public is 
of great importance; taking into account local needs, terms and respecting the principle of subsidiary. Resulting from it, increased attention has been paid to civic participation recently, which is a generally inseparable part of democratic regimes, with respect to the problems associated with democracy. It's a complex phenomenon that can be defined as active participation of citizens in solving the social problems, as well as in managing the public affairs. It is not limited just to the subjective acceptance of public affairs in private, but it also assumes citizen involvement in public affairs through concrete acts.

\section{Security and its spatial impact: theoretical determination of the terminology}

Society's concern in the problems connected with the urbanization process is a permanent phenomenon. It's provable that the degree of citizen participation in public affairs is closely linked with the perception of safety within the particular environment. In this context, it should be recognized that the safety either as an objective status or subjective feeling of the individual represents an essential prerequisite for sustainable territorial development. Finka and KluvánkováOravská [1] state that on the one side, the interest of the general public, academia and the third sector in the issue of safety is gratifying, but on the other side, safety becomes a political issue that causes many measures and activities aimed at safety to lead to fragmentation of sources and efforts into partial and often counterproductive solutions in order to declare the political sphere concern in the problems of common people. We often forget complexity, spatial and temporal coherence of safety problems. The consequences are being solved instead of the reasons of particular problem origin.

In this context, Ivančík [2] points out that the security of each referential subject or individual, group or state is limited by safety environment and, from an economic point of view, by resources available within the entity. Trigilia [3] defines a safe environment as the one in which individual reference entities pursue their security interests in the interaction with sources, respectively bearers of security threats. From the economic theory point of view, security is an estate that can be public or private. If the security is being ensured as a public estate, it's ensured by particular subjects and institutions belonging to the public sector. Šimák [4], Klučka [5] and Hudáková et al. [6] characterize the public sector as a part of social reality, or a subsystem of particular spheres of social life in public ownership where, from political point of view, the decisions are made in public elections and public control is applied here, while the purpose of public sector functioning is the fulfillment of public interest and administration of public affairs. The public sector is the product of state public policy. In this context, Beneš [7] points out that public administration is an inseparable part of the public sector that determines the complexity of legally qualified activities performed by executive bodies of public administration and public legal entities. Spatial security represents the problem that is generally known and accepted, but it lacks a clear definition of this term. In this context, Hamalová and Belajová [8] and ESDP [9] state that, traditionally, the policy of urban security is being 
interpreted in the context of some security partial problem and certain generally appointed interpretation is absent. In this context, probably the most integrated definition of urban security is provided by Finka $[10,11]$ who defines it as any kind of human security within public places of a built-up area.

\section{Public participation as a tool for the creation of public affairs}

Citizen participation in public affairs, so-called cons or co-decision, makes presumptions for improving the quality of all-society development in the territory where it takes place. Šikula [12] states that civil participation presents a large social concept having multidisciplinary character and society-wide impact. Based on the principle of subsidiary, partnership and trust, it makes presumptions for the implementation of practical needs and experience of citizens who live in a particular territory, respectively participate in its development in some way. Strussová and Petríková [13] (see also [14]) point out that, if there's an assumption the citizens will face the consequences of public decisions, their involvement in all the stages of this development process is obvious and legitimate and that makes the potential for higher transparency and effectiveness of the whole process. Citizens' participation and involvement into creation, realization and control of these processes increase their sense of control over environment, their independence, self-determination, responsibility, while, on the other side, decrease disposal, anonymity and feelings of vagueness resulting in losing their feeling of security within a particular environment.

Participation of particular subjects in the creation of development processes of territorial development increases the citizens' identification with a particular space and makes the feeling of fellowship to this territory and motivation to beneficial behavior for the development of all the community, as well as the territorial unit concerned. It often counterweighs the opinions and decisions of more powerful bodies participating in the development of a particular territory. Based on an allegation by Pirošík [15], we claim that participation is an effective tool for achieving the most effective public decisions. Although public participation is from a formal point of view, legally established in many acts, such as the Constitution of the Slovak Republic, Law of Municipalities, administrative procedure, Law of Free Access to Information, so-called info law, Law of Regional Development, Law on Construction, Waste Act, Clean Air Act, Act on Environmental Impact Assessment, etc., and more, it has a specific historical background in the environment concerned, it has not become an homogeneous part of Slovak political culture, yet. Zemanovičová and Gyárfášová [16] and Lin [17] point out the model of public involvement into public decision-making in which the citizen represents an active element within the participial model of public administration in the way that, besides delegating the rights to deputies, he/she tries to be responsible and advocates and makes institutions necessary for the effective operation of parliamentary democracy within the democratic environment through lobby forming. 
The World Bank study entitled Participation in Practice: The Experience of the World Bank and Other Stakeholders, 1996, diagnoses barriers of enforced participation in planning the developmental projects as follows:

- Lack of governmental commitment to pass participial approach;

- Unwillingness of the administrative apparatus of the project to give up the control over project activities and directives;

- Lack of project workers' incentives and skills that would encourage them to pass participial approach;

- Limited organization ability at a regional level and insufficient investments in building community opportunities;

- Late participation take off;

- Disbelief between the government and involved entities at a regional level.

Responsible public officials and representatives often underestimate the effectiveness of the implementation of methods and tools of public participation in decision making processes. They perceive it as a threat to their influence and power. These negative attitudes can be subject to various reasons.

\section{The survey methodology}

In our study, we focus our attention on citizens' participation, respectively, their associations, in the creation of public affairs, their participation in public decision-making and the security perception in the territory of the Euro region Biele-Bíle Karpaty. The goal of the presented research study is to draw attention to the analysis of facts and development trends within the development of civic participation and its barriers in the Euro region Biele-Bíle Karpaty in public affairs, in context with security perception by the citizens of the Euro region Biele-Bíle Karpaty; both the Czechs and the Slovaks. The main goal was to generate connections and relationship of public participation in its creation and evaluation, as an entity which this indicator directly refers to. The main goal of the research was to analyze facts of security perception by inhabitants of the Euro region Biele-Bíle Karpaty of both Czech and Slovak parties. Acquiring, collecting and the assessment of selected data and valid information on subjective security perception, as a category of life quality of the Euro region inhabitants from the point of view of particular target groups will make the basis for the optimization of a communicative strategy of local self-governments aimed at effective participation of inhabitants and entities participating in the development of public affairs of the territory concerned in the context of development policies of regional sustainable development.

The basic framework for studying the problem is formed by relations between territorial development continuity and the actual use of territorial potential of the territorial structure. A partial goal of research was to analyze the facts: 
- Use of the participation potential of Euro region Biele Karpaty by its inhabitants, from both the Czech and Slovak sides;

- Identification of the most significant forms of partnerships contributing to the realization of social and economic development of Euro region Biele Karpaty;

- Analysis of security perception as the category of life quality, as well as the value system of individual actors of this development process from the point of view of particular target groups.

Methodology of logical research has been applied in the paper, e.g. comparative method, analytic-synthetic method at examining the particular tools of spatial management, respectively, an analytic-synthetic method at making conclusions.

Research methodology is based on the principle of a multilevel complex analysis of selected activities and factors affecting the development of settlement structure. The processing itself has been divided into three developmental stages:

- Analysis of theoretical knowledge and practical experiences compatible with the implementation of selected tools of spatial management and their territorial impacts on the development of settlement structures;

- Analysis, quantification and application of qualitative methods at assessment of synergic and cumulative impacts in the context of sustainable development and the system of planning mechanisms;

- Summary of conclusions for practical application of progressive approaches to assessing the developmental potential of a settlement unit.

The comprehensive survey has been carried out within the project KEGA No.005 DTI-4-2014 sectorial integration of spatial impacts of the safety management of environmental risks on a research specimen of 360 respondents in the Czech Republic, respectively 360 respondents from the Slovak Republic in the period from May 2014 to June 2014. Data collection has been done by electronic on-line survey, as well as by standardized questionnaire (so-called exploration method), thus it was the collection of primary data. The on-line survey procedure was as follows:

- Questionnaire in final form was programmed into web form and placed on the Internet and social networks;

- After successfully testing the questionnaire, the respondents addressed by e-mail containing the survey web address, as well as log-in data;

- During the on-line survey, we could check information on the survey state, quota-repletion, respectively continuous statistics at any time, being a significant advantage of processing. Data collection was closed up after filling the specimen and quotas;

- Collected data were checked with regard to the consistency, seriousness and logic reference of the answers. Wrong answers (conversations) were deleted. Statistic signs of respondents were added to data and they were consequently processed using a statistics program. 


\section{Methodology of diffusion analysis of selected participation barriers}

Using the diffusion analysis of particular barriers within the Czech and Slovak Republics, we can determine whether the perception of selected barriers in these countries is identical. Particular respondents' replies were expressed by the scale where number 1 represented the smallest influence, to the largest influence, expressed by the number 10. Diffusion analysis processing is numerically demanding, therefore it was carried out with the support of statistical software STATGRAPHICS Centurion XV [18].

Selected barriers of participation of self-government and public administration:

1. Lack of governmental commitment to pass participial approach;

2. Unwillingness of the administrative apparatus of the project to give up control over project activities and directives;

3. Lack of project workers' incentives and skills that would encourage them to pass participial approach;

4. Limited organizational ability at a regional level and insufficient investments in building community opportunities;

5. Late participation take off, skepticism of getting some changes;

6. Disbelief between the government and involved entities at a regional level.

Diffusions analysis of selected barriers plays a significant role in assessing the survey and discussion in a particular field. Diffusion analysis of selected barriers consists of the following stages:

- Define selected characteristics (medium value, diffusion) from subject case study in selected barriers of the countries.

- Make a decision on the suitability of the use of parametric or nonparametric test in diffusion analysis of the barriers with regard to the conditions set on their realization.

- Determine if medium values of selected barriers between particular countries are identical by testing the diffusion hypotheses of selected barriers using the parametric F-test and non-parametric Kruskall-Wallis test.

\section{Methodology of diffusion analysis of selected participation barriers}

Elementary characteristics in the given field of research, such as medium value and diffusion, are shown in the tables below. 
Table 1: Medium values of participation barriers of self-government and public administration.

\begin{tabular}{|c|c|c|}
\hline Barriers & SK & CZ \\
\hline 1. & 6.25 & 5.98 \\
\hline 2. & 2.79 & 3.08 \\
\hline 3. & 4.24 & 1.16 \\
\hline 4. & 1.23 & 2.69 \\
\hline 5. & 5.61 & 4.41 \\
\hline 6. & 2.08 & 5.71 \\
\hline
\end{tabular}

Table 2: Participation barriers' diffusion of self-government and public administration.

\begin{tabular}{|c|c|c|}
\hline Barriers & SK & CZ \\
\hline 1. & 0.45 & 0.78 \\
\hline 2. & 1.28 & 1.97 \\
\hline 3. & 2.08 & 0.94 \\
\hline 4. & 2.19 & 0.56 \\
\hline 5. & 1.16 & 1.37 \\
\hline 6. & 1.58 & 0.67 \\
\hline
\end{tabular}

Diffusion analysis is carried out using the parametric F-test, respectively nonparametric Kruskall-Wallis test. The parametric test can be performed subject to the following two conditions:

- Homoscedasticity - identity of participation barriers' diffusion of selfgovernment and public administration in particular countries. Results are summarized in Table 3.

- Value normality - probable model of normal value diversion of barrier assessment of self-government and public administration between countries. Results are summarized in Table 4.

The non-parametric Kruskall-Wallis test can be performed subject to the presence of diffusion homoscedasticity. However, risk values in particular sectors are not distributed normally. 
Table 3: Bartlett's test for verifying the homoscedasticity.

\begin{tabular}{|c|c|}
\hline Barriers & Bartlett's test [P-value] \\
\hline 1. & 0.085 \\
\hline 2. & 0.457 \\
\hline 3. & 0.614 \\
\hline 4. & 0.147 \\
\hline 5. & 0.226 \\
\hline 6. & 0.071 \\
\hline
\end{tabular}

Table 4: $\quad$ Pearson's $\chi^{2}$-test for verifying the normality of barrier values.

\begin{tabular}{|c|c|}
\hline Barriers & Pearson's $\chi^{2}$-test [P-value] \\
\hline 1. & 0.251 \\
\hline 2. & 0.741 \\
\hline 3. & 0.047 \\
\hline 4. & 0.009 \\
\hline 5. & 0.014 \\
\hline 6. & 0.189 \\
\hline
\end{tabular}

The results of Bartlett's test say that there is $95 \%$ probability of accepting the hypothesis of identical diffusions of selected barriers from self-government and public administration. Pearson's $\chi^{2}$-test says that there is $5 \%$ importance of barriers $1^{\text {st }}, 2^{\text {nd }}$ and $6^{\text {th }}$ being normally distributed. In such barriers are all the assumptions for realization parametric F-test of diffusion analysis filled. As the P-value of Pearson's $\chi^{2}$-test within the $3^{\text {rd }}, 4^{\text {th }}$ and $5^{\text {th }}$ barriers are lower than significance level 0.05 , we refuse hypothesis on normal distribution in given barriers of self-government and public administration. Assumptions for realization of the non-parametric Kruskall-Wallis test of diffusion analysis of barriers of self-government and public administration are fulfilled in these barriers. Barriers' diffusion analysis results with the help of a parametric and non-parametric test are compiled in Table 5 and 6.

Table 5: $\quad$ Parametric F-test for barriers' diffusion analyses.

\begin{tabular}{|c|c|}
\hline Barriers & F-test [P-value] \\
\hline $\mathbf{1 .}$ & 0.015 \\
\hline $\mathbf{2 .}$ & 0.144 \\
\hline $\mathbf{6 .}$ & 0.039 \\
\hline
\end{tabular}


Table 6: Non-parametric Kruskall-Wallis test barriers' diffusion analyses.

\begin{tabular}{|c|c|}
\hline Barriers & Kruskall-Wallis test [P-value] \\
\hline 3. & 0.047 \\
\hline 4. & 0.002 \\
\hline 5. & 0.098 \\
\hline
\end{tabular}

Interpretation of the results of barrier diffusion analysis of self-government and public administration from tables 5 and 6 is as follows:

We accept the hypothesis, probable in $95 \%$, that the following medium values of barrier assessment between Czech and Slovak respondents are identical. They are:

- Unwillingness of the administrative apparatus of the project to give up control over project activities and instruction;

- Too late participation start; disbelief that something can change.

From a statistical point of view, there are no significant differences in the assessment of the barriers of self-government and public administration (0.05 significance). Other barriers of self-government and public administration are statistically important in their diffusion difference assessment of Slovak and Czech respondents.

\section{Survey assessment and discussion}

Practical implementation of current public participial activities into the processes of territorial management has developed into the stage when it has become the part of most national systems of settlement development and territorial planning. The legal system of developed democracies covers and ensures specific conditions of citizen participation, with respect to their associations, in public decision making through the laws becoming tools of practical public participation in decision making processes. It's not only creation of the conditions for public participation, but more active and purposeful engagement into decision making processes with public consequences. The citizens gets the legal right to be informed sufficiently about administrational activities and subjected coherence of decision making processes and activities, has the right to present his opinions and reflections. This way he gets into the position of being an equal partner with all participants in these processes. Targeted and meaningful implementation of participation methods and tools increases the feeling of control over the environment, independence, self-determination and responsibility, decreases disaffection, anonymity and the feeling of irrelevance, and finally, participation increases population identification with the territory where he lives.

Assessment views of respondents on solved problems from both countries, in spite of all-society changes and twenty years of independent existence of both 
republics, are surprisingly closely related. According to our opinion, historical roots and territorial cohesion has a strong impact on the point of view on solved problems.

As research results show, the most respondents assessed critically "game rules" having been established in the new society during twenty years.

\begin{tabular}{|c|c|c|}
\hline \multicolumn{3}{|c|}{$\begin{array}{l}\text { Question: } \\
\text { Do you think that your life quality has improved in comparison with your } \\
\text { ancestors before } 1989 \text { ? }\end{array}$} \\
\hline \multirow[t]{2}{*}{ Yes } & $\begin{array}{l}S K \\
{[\%]}\end{array}$ & $\begin{array}{l}C Z \\
{[\%]} \\
\end{array}$ \\
\hline & 26 & 22 \\
\hline No & 30 & 28 \\
\hline It is still the same & 37 & 26 \\
\hline $\begin{array}{l}\text { I'm not able to judge the } \\
\text { state objectively }\end{array}$ & 7 & 24 \\
\hline \multicolumn{3}{|c|}{$\begin{array}{l}\text { Question: } \\
\text { Does the new situation open new possibilities for you "to have a good } \\
\text { time"? }\end{array}$} \\
\hline Yes & 31 & 25 \\
\hline No & 37 & 32 \\
\hline The same & 26 & 26 \\
\hline $\begin{array}{l}\text { I'm not able to judge the } \\
\text { state objectively }\end{array}$ & 6 & 17 \\
\hline
\end{tabular}

As far as equality of the citizens before the law is concerned, only one fourth $(26 \%)$ thought that they are getting better than what their ancestors had before 1989. On the other hand, more than two thirds considered the situation as the same $(37 \%)$ or even stated that equality before the law has decreased $(30 \%)$. Concerning prevalence of positive evaluation of the state of political rights and freedoms, it's obvious that, according to respondents, the problem consists not on paper, but in applying equality before the law in everyday life. A similar problem is, according to the predominant part of the publicity, even a limited chance to gain solid social status based on honest work. Only less than one third of respondents $(31 \%)$ thought that the new era gives them better possibilities than the generation of their parents, while almost two thirds hold the view that they get either the same $(26 \%)$ or even worse $(37 \%)$.

This process has been proved in its wider context in losing civil interest in public affairs. In this historically-spatial cohesion, we understand civil participation in the subject territory as a process implementing the points of view of all interested subjects into administration, development, management and use of the subject territory. It's the process of enhancement of own ideas and realization of the conditions, helping to form settlement identity and fellowship with the local community. 
Practically, responsible workers and representatives of public administration and self-governments often underestimate the effectiveness of implementation of methods and tools of participation of the mentioned publicity into decision making processes; they perceive it as a threat, wasting time, power or influence. That's the reason why we focused our attention in our research on the perception of potential barriers of particular subjects' participation in public affairs.

\section{Conclusion}

In the end, we can confirm the basic axiomatic question of the survey, making the platform for searching for the answers and relations on the question if the extent of citizen participation in public affairs is closely related to the perception of security of a particular environment confirmed this cohesion in particular space works and is dominantly linked to perception of life quality of citizens and stakeholders of various developmental processes. It has an important impact on the creation of developmental decision making. Municipalities gain the citizens for their decisions by making space for civil participation, whereby on one hand it creates potential for conflict elimination within the community, on the other hand, interactive bonding between the citizens and self-government creates conditions for many innovative ideas and important feedback that contributes to strengthening the community and consequently to decreasing corruption behavior within self-government. In this context, we would like to point out the statement by Lin [17] that civil participation has the processional character bearing democracy process of the society and its public life. It transforms personal and group interests of regional and local communities with public interests. Thus, it is an interactive process of change in which the environment and the citizen itself are changing and the citizen stops being careless towards his/her settlement and social environment and takes responsibility for activities in his/her surroundings.

\section{Acknowledgement}

The authors would like to thank the Ministry of Education of the Slovak Republic for its support on the grant project KEGA Project no. 005DTI-4/2014.

\section{References}

[1] Finka, M., Kluvánková-Oravská,T., 2010. Koncept polycentricity $v$ súčasnej teórii a praxi spravovania územia, In: Prognostické práce, 2010, vol. 2, no. 1, pp. 23-37, Prognostický ústav SAV Bratislava, 2010, ISSN 1337-9666

[2] Ivančík, R. 2012. Bezpečnost' z pohl'adu ekonomickej teórie. In Politické vedy. [online] Fakulta politických vied a medzinárodných vzt’ahov UMB, Banská Bystrica Roč. 15, č. 3, 2012. ISSN 1338-5623, s. 100-124. Dostupné na internete: http://www.fpvmv.umb.sk/userfiles/file/3_2012 /IVANCIK.pdf 
[3] Trigilia, C. 2001. Social Capital and Local Development. In European Journal of Social Theory, 4(4), London: Sage Publications, 2001, Available from: http://est.sagepub.com/content/4/4/427

[4] Šimák L., 2004. Krízový manažment vo verejnej správe, Fakulta špeciálneho inžinierstva, Žilinská univerzita v Žiline, Žilina 2004 ISBN 80-88829-13-5

[5] Klučka, J. Ekonomická efektivnost'v projektoch bezpečnosti. Zborník z 15. vedeckej konferencie FŠI, Žilina, 2010, str. 371-374, ISBN 978-80-55402024-0

[6] Hudáková, M., Bugánová, K., Lusková, M. Small and Medium-Sized Enterprises Business Risks in Slovakia. In: WMSCI 2014: The 18th World Multi-Conference on Systemics, Cybernetics and Informatics, Orlando, Florida, USA, 2014. ISBN -13: 978-1-941763-05-6. p. 45

[7] Beneš, M., 2006. Konkurenceschopnost a konkurenční výhoda, Working Paper č.5, Centrum výskumu komerční schopnosti české ekonomiky, Brno, 2006. ISSN 1801-4496

[8] Hamalová, M., Belajová, A., 2011. Komunálna ekonomika a politika, vyd. Sprint dva, Bratislava 2011, ISBN 978-80-89393-38-1

[9] ESDP - European Spatial Development Perspective (ESPD), Forwards balanced and Sustainable development of the Territory of the European Union, European Communities 1999, ISBN 92-828-7658-2

[10] Finka, M. 2001. Interdisciplinárne aspekty vývoja priestorovej kvality systémov osídlenia. Bratislava: Road, 2001, ISBN 80-88999-09-X

[11] Finka, M., 2006. Koncept polycentricity v súčasnej teórii a politike priestorového rozvoja, In: Petríková, D., Finka, M., trajektórie územného rozvoja, Spectra 2006. ROAD Bratislava, ISBN 978-80-88999-31-7

[12] Šikula, M. Dlhodobá vízia rozvoja slovenskej spoločnosti, A Long-Term Vision of the Slovak Society Development. Second (unchanged) edition. Bratislava: ÉÚ SAV 2010. 274 s. Druhé, nezmenené vydanie. ISBN 97880-7144-168-7

[13] Strussová, M., Petríková, D., 2009. Možnosti a predpoklady občianskej participácie v udržatelnom sídelnom rozvoji, Sociológia 41, 2009, č. 4, ISBN ISSN 1336-8613

[14] Sustainable Development of the Territory of the European Union, European Communities 1999. ISBN 92-828-7658-2

[15] Pirošík, V. 2004. Protikorupčné ustanovenia v novele správneho poriadku. In.: Pod lupou. Newsletter Transparency International Slovensko.

[16] Zemanovičová, D. Gyárfášová, O. 2000. Korupcia na Slovensku z hladiska spravovania vecí verejných. Bratislava: Centrum pre hospodársky rozvoj - Transparency International Slovensko. In: Róbert Vico - vydavatel'stvo, 2000. ISBN 80-967382-5-9

[17] Lin, 2001. Social Capital: A Theory of Social Structure and Action, Cambridge University Press, New York, ISBN 978-521-47431-3

[18] STATGRAPHICS: Software Statgraphics Centurion XV. 2014. [online] [cit. 25 March 2014]. Available: http://www.statgraphics.com/support/ download_center.aspx 